\title{
Phenotypic correlation of characteristics in the gilt performance test with an average number of live-born piglets through all achieved births, during the reproductive exploitation
}

\author{
[ Ligação fenotípica de características no teste de desempenho de leitões com um número médio de leitões \\ nascidos vivos durante todos os nascimentos realizados, durante a exploração reprodutiva]
}

I. Radović, S. Dragin, N. Katanić, D. Beuković, I. Stančić, M. Mirkov, M.P. Horvatovic

Faculty of Agriculture - Novi Sad, Serbia

\begin{abstract}
Reproductive efficacy of sows dictates the level of profitability of the production itself, and the moment of testing and selection of gilts for breeding (as the parents of a future generation), represents a very important moment. Given the fact that the selection of gilts for breeding is partly based on the weight-gain in the test, in this study we examined the influence of a daily weight-gain of gilts in the test of the manifestation of important reproductive characteristics - the size of the litter of the first and the other parities, as well as the percentage of sows that gave birth in relation to previous breeding process. Data of the 11637 tested gilts that completed the performance test have been used for the test. The studied characteristics were: the weight-gain at the end of the test, the number of live-born piglets, the number of stillborn piglets and the number of grown-weaned piglets in the first litter and the total number of live-born piglets, the total number of stillborn piglets and the total number of grown-weaned piglets. The results obtained in this study showed the effect of weight-gain in the reproductive efficacy test in the number of the live-born piglets in the first and from the 2nd to the 9th parity, as well as the percentage of the sows included in the next breeding process. By including all selected independent variables that showed the adequate statistical significance in correlation with the dependent variable, the determination coefficient rises to a value of 0.098 which represents $9.80 \%$ of the influence on the dependent variable, that can be explained by the independent variable, which leads to the conclusion that the binding strength between the variable "average live" and all the independent variables: "the number of litters", the MLD depth" and "the back-fat thickness", is very weak, which is not a rare case in multiple regression.
\end{abstract}

Keywords: sow, gilt, parity, weight-gain, restocking of sows, size of the litter

\section{RESUMO}

A eficácia reprodutiva das porcas dita o nível de rentabilidade da própria produção, e o momento do teste e seleção de leitoas para reprodução (como os pais de uma geração futura) representa um momento muito importante. Dado o fato de que a seleção de leitoas para criação é parcialmente baseada no ganho de peso no teste, neste estudo examinamos a influência de um ganho de peso diário de leitoas no teste da manifestação de importantes características reprodutivas - o tamanho da ninhada da primeira e das outras paridades, assim como a porcentagem de porcas que deram à luz em relação ao processo de criação anterior. Os dados das 11637 leitoas testadas que completaram o teste de desempenho foram utilizados para o teste. As características estudadas foram: o ganho de peso ao final do teste, o número de leitões nascidos vivos, o número de leitões natimortos e o número de leitões desmamados na primeira ninhada e o número total de leitões nascidos vivos, o número total de leitões natimortos e o número total de leitões desmamados. Os resultados obtidos neste estudo mostraram o efeito do ganho de peso no teste de eficácia reprodutiva no número de leitões nascidos vivos na primeira e da segunda à nona paridade, bem como a porcentagem de porcas incluídas na próximo processo de criação. Ao incluir todas as variáveis independentes selecionadas que mostraram a significância estatística adequada em correlação com a variável dependente, o coeficiente de determinação sobe para um valor de 0.098 que representa $9.80 \%$ da influência sobre a variável dependente, que pode ser explicada pela variável independente, que leva à conclusão de que a força de ligação entre a

Recebido em 20 de dezembro de 2017

Aceito em 31 de agosto de 2018

E-mail: ivan.radovic@stocarstvo.edu.rs 
variável "média viva" e todas as variáveis independentes: "o número de ninhadas", a profundidade MLD "e" a espessura de gordura "é muito fraca, o que não é raro caso em regressão múltipla.

Palavras-chave: porca, leitão, paridade, ganho de peso, repovoamento de porcas, tamanho da ninhada

\section{INTRODUCTION}

In addition to poultry production, pig production is the most intensive type of production which requires the perfect functioning of all critical points in technology. Throughout the process, we place a great deal of emphasis on the production of breeding materials, primarily the gilts, which will be included in production after proper selection, assuming that they remain there for a long time, in order to cover the costs of purchasing and growing. In this case, we primarily think on its longevity while achieving maximum reproductive performance.

In addition, the current problem in pig production is the high percentage of elderly sows, which can rise up to $30 \%$ and on our farms, even, up to $50 \%$ (Radović et al., 2003). In order to ensure a sufficient number of animals for restocking, it is necessary to devote considerable attention to the growing of breeding gilts in order to ensure the appropriate body weight and age at the time of the first possible insemination, and to ensure that the gilts are included in the breeding process on the most efficient way (Radović et al., 2003). Factors influencing the moment of reaching the puberty in gilts are numerous: the influence of race, diet and ambient (Lena Eliasson - Selling, 2001; Stančić and Šahinović, 1998; Stančić et al., 2009a; Stančić et al., 2009b). Lately, there is a question of the ,human factor", because it influences the complete process of reproduction technology (Teodorović and Radovic, 2004).

Due to the large number of factors affecting the moment of full maturity of the gilts and later, their reproductive efficacy, there is an interest in finding a link between the fattening properties of gilts and their subsequent reproductive potential, and an aggravating fact is that the reproductive and fattening properties are characterized by different degree of inheritance, so it is not possible to effectively apply the same selection methods (Gerasimov et al., 1997) in order to obtain an appropriate phenotype with good reproductive properties (Wise et al., 1993).
It is precisely for this reason that it is important to determine whether there is a connection between the growth rate and the subsequent reproductive efficiency of sows.

\section{MATERIALS AND METHOD}

Data from 8 large farms in Vojvodina, Serbia (11637 tested gilts) was used. The entire cycle of production was set on those farms, from piglets to grown-up pigs. The performance test was carried out according to the instructions for the implementation of gilts performance test, which were given by the main breeding organization at the Department of Animal Science, Faculty of Agriculture, Novi Sad, Serbia.

The following features were examined: age of gilts at the end of the test, body weight at the end of the test, daily increase of the weight in the test, the back-fat and the loin-fat thickness, MLD depth, percentage of meat in the hull, breeding value of gilts assessed by the selection index (SI) and exterior.

The fat thickness and depth of MLD were measured by using the Kraut Kramer S22 ultrasound device. Measurement of the back-fat thickness and the MLD depth was done in the following places: - The loin-fat thickness (DLS1) - between 3rd and 4th loin vertebra (viewed from the last loin vertebra), $7 \mathrm{~cm}$ laterally from the backline - The back-fat thickness (DLS2) between $3 \mathrm{rd}$ and 4 th rib in the back, $7 \mathrm{~cm}$ laterally from the backline, - The depth of the MLD in the back part - between 3rd and 4th rib, $7 \mathrm{~cm}$ laterally from the backline.

The number of live-born piglets during the reproductive exploitation is derived from the database of all observed farrows.

At the beginning of the research, data were analyzed empirically and logically, projecting extreme value and accidents, taking into account that they do not cast out the key explaining factors. All samples were tested on the normality of the distribution, using Kolmogorov Smirnov and Shapiro Wilk (Wilk) tests. 
For each dependent variable "average live" - the number of live-born piglets were performed multiple regression analysis "Stepwise" method, the key explanatory variables in the regression model was found and then odds were calculated.

The "choice of variables" method called gradual regression (Stepwise regression, Backward, Forward) was used as a combination method of gradual expansion and decrease the dimensions of the model. The peculiarity of this model is that the significance of each variable included in the model are reviewed at every step, because some variables, whose presence is significant in the first step, may lose significance in the following steps (there is inter-correlation). Decisions on exclusion and inclusion in the model were brought in on the basis of $F$ test. The process of selection of variables according to the defined exclusion criteria from the model is finished when no new variable could be included in the model, and no variable could be excluded from the model.

The specificity of this model is that the significance of each variable involved in the model is reviewed at each step since some variables, whose presence is significant in the first step, can lose significance in the next steps (there is intercorrelation). Decisions on exclusion and inclusion in the model were made based on the $\mathrm{F}$ test. The procedure for selecting variables according to defined exclusion criteria ended when no new variable could be included in the model or no variable could be excluded from the model.

The problems that arose during the implementation of regression models were identified and eliminated or reduced by applying adequate statistical analytical procedures: (Residual mean square, Mallows criterion PRESS criterion, AIC criterion - Akaike's Information Criterion, SBC criterion - Schwartz's Bayesian Criterion, PC criterion - Amemiya's Prediction criterion).

\section{RESULTS}

This section presents the results of statistical characteristics of the performance test (external traits, weight at the end of the test, age at the end of the test, the test daily gain, back-fat thickness at loins region, bacon thickness of the dorsal part, the MLD depth, the number of litters, SI, the percentage of meat in the body) and their impact on reproductive performance of sows (live-born piglets) in parities during the reproductive period. Table 1 shows the descriptive statistics of the parameters analyzed in the performance test and the results of a litter size.

Table 1. Descriptive statistics feature of the performance test and litter size during the operation on the total sample of all races

\begin{tabular}{|c|c|c|c|c|c|c|c|c|c|c|c|c|}
\hline 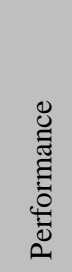 & 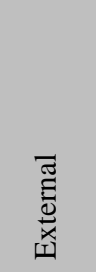 & 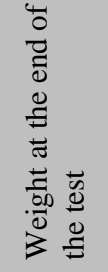 & 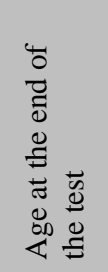 & 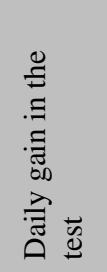 & 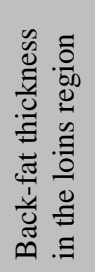 & 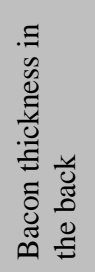 & 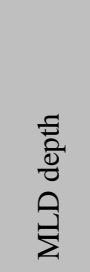 & 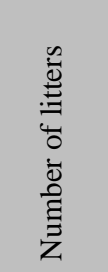 & 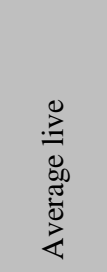 & $\bar{n}$ & 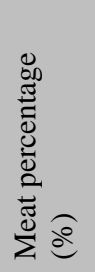 & 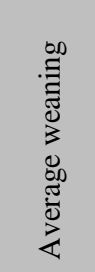 \\
\hline $\mathrm{N}$ & 6,657 & 11,636 & 11,637 & 11,637 & 9,252 & 9,278 & 9,081 & 11,637 & 11,632 & 9,034 & 9,694 & 10,815 \\
\hline $\bar{x}$ & 4.45 & 106.69 & 200.27 & 533.33 & 14.20 & 15.24 & 66.31 & 3.09 & 10.47 & 100.22 & 56.79 & 12.04 \\
\hline$S_{x}$ & 0.01 & 0.12 & 0.13 & 0.57 & 0.053 & 0.10 & 0.16 & 0.02 & 0.03 & 0.04 & 0.13 & 0.12 \\
\hline SD & 0.75 & 13.16 & 13.71 & 61.16 & 4.54 & 8.79 & 13.39 & 2.56 & 2.86 & 11.95 & 5.40 & 4.14 \\
\hline $\min$. & 1.00 & 70.00 & 170.00 & 400.00 & 4.00 & 5.00 & & 1.00 & 1.00 & 60.00 & 48.00 & 1.00 \\
\hline мax. & 5.00 & 170.00 & 230.00 & 829.00 & 31.00 & 97.00 & 99.00 & 18.00 & 21.00 & 140.00 & 80.00 & 35.00 \\
\hline
\end{tabular}

Based on the results of the total sample of all races, average weight at the end of the test was $106.69 \mathrm{~kg}$ with an average daily growth rate in the assay of $533.33 \mathrm{~g}$. The standard deviation was $13.16 \mathrm{~kg}$ of the of variable body weight at the end of the test, 13.71 days in age at the end of the test and $61.16 \mathrm{~g}$ in daily weight gain during the test. The average breeding value of gilts estimated by Selection Index stood at 100.22 with a standard deviation of 11.95 . 
Quality parameters of the body, on the same sample, showed the following values: $14.20 \mathrm{~mm}$ average thickness of fat over loins, $15.24 \mathrm{~mm}$ average thickness of fat in the back section, $66.31 \mathrm{~mm}$ average MLD depth and an average of 56.79 percent of meat. The standard deviation was $4.54 \mathrm{~mm}$ for variable of fat thickness over loins; $8.79 \mathrm{~mm}$ thick bacon at the lumbar part, MLD depth was $13.39 \mathrm{~mm}$ and 5.40 percent of meat in the body.

Regarding reproductive parameters, the value of the average number of litters in the total sample was 3.09 with the average number of 10.47 live piglets and 12.04 average weaned piglets. The standard deviation was 2.56 at a variable number of litters, the number of piglets born alive was 2.86 and number of weaned piglets was 4.14.

In further studies, the hypothesis by Kolmogorov - Smirnov test was tested and it was found that the normality of the distribution of the dependent variables "average live" and "average weaning" is in relation to the independent variables (characteristics of the performance test). By statistical examination the difference between the assumed and empirical distribution function was observed and normal distribution was confirmed.

For larger samples with the same goal, we used Shapiro - Wilk tests, where the vector of expected values of the order statistics of a random sample fits the standard normal

In Figure 1 we can see the line of movement theoretically expected normal distribution poles and deviation values of independent variables (performance characteristics of the test) compared to the expected distribution and the actual distribution.

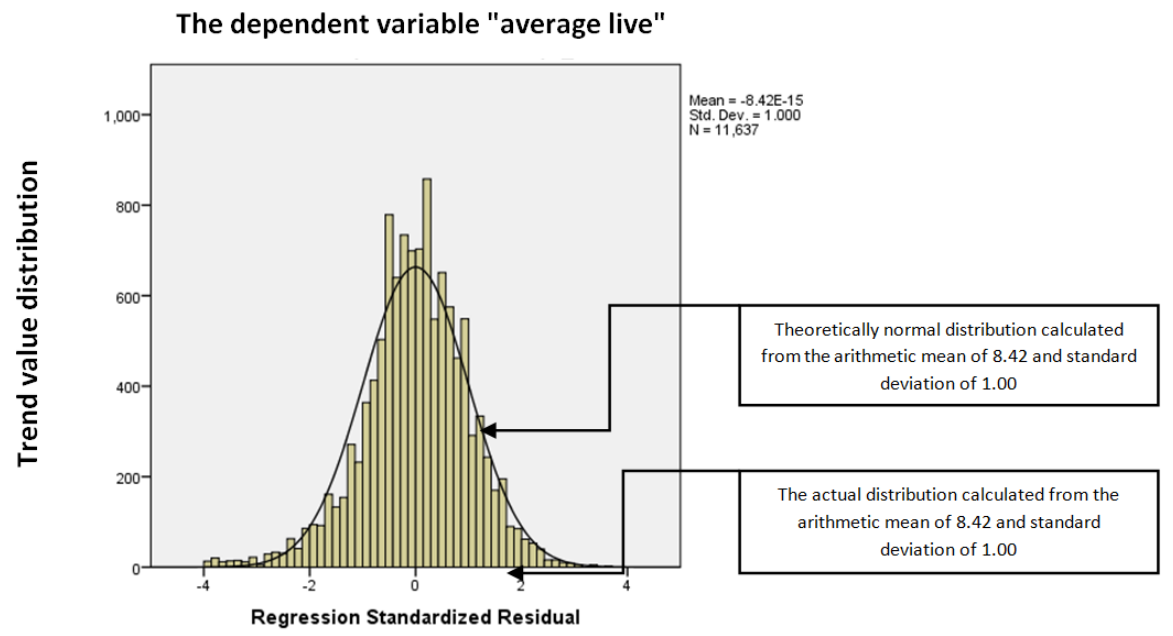

Figure 1. Trend of the value of the distribution of the dependent variable "average live" in relation to the independent variables (characteristics of performance test).

In Figure 2, the correct line represents the expected normal distribution and the thickened line represents value of the independent variables observed during the test. All points on the thickened line follow the expected distribution with minimal deviation so we used graphical way to conclude that all variables are normally distributed. 
The movement of property values from the performance test

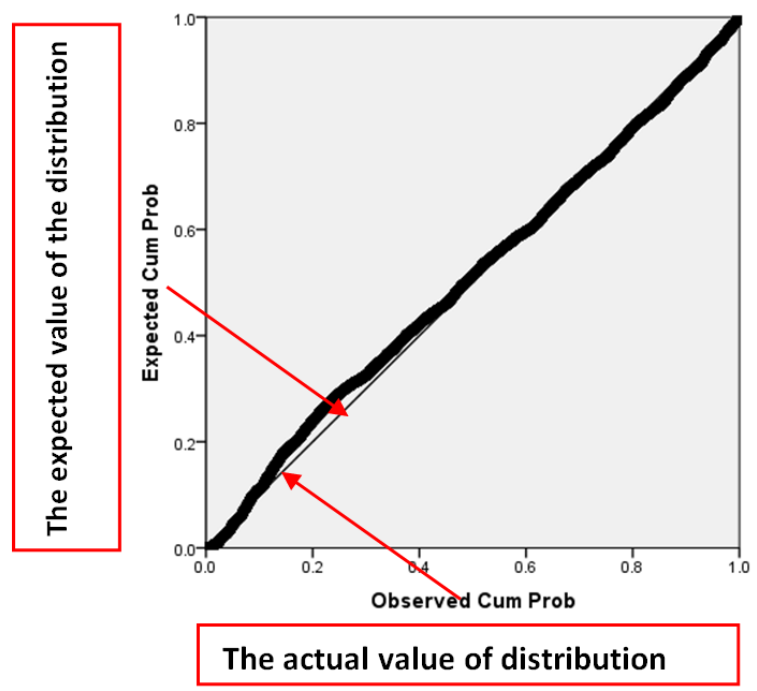

Figure 2. Normal Q-Q Plot for the dependent variable "average live"

Figure 3 displays size, direction and deviation of characteristics from a performance test in relation to the normal distribution. Each point was obtained by subtracting expected from the observed. It is worth noting that the distribution is normal when the points are grouped around zero in no particular order as it is the case here.

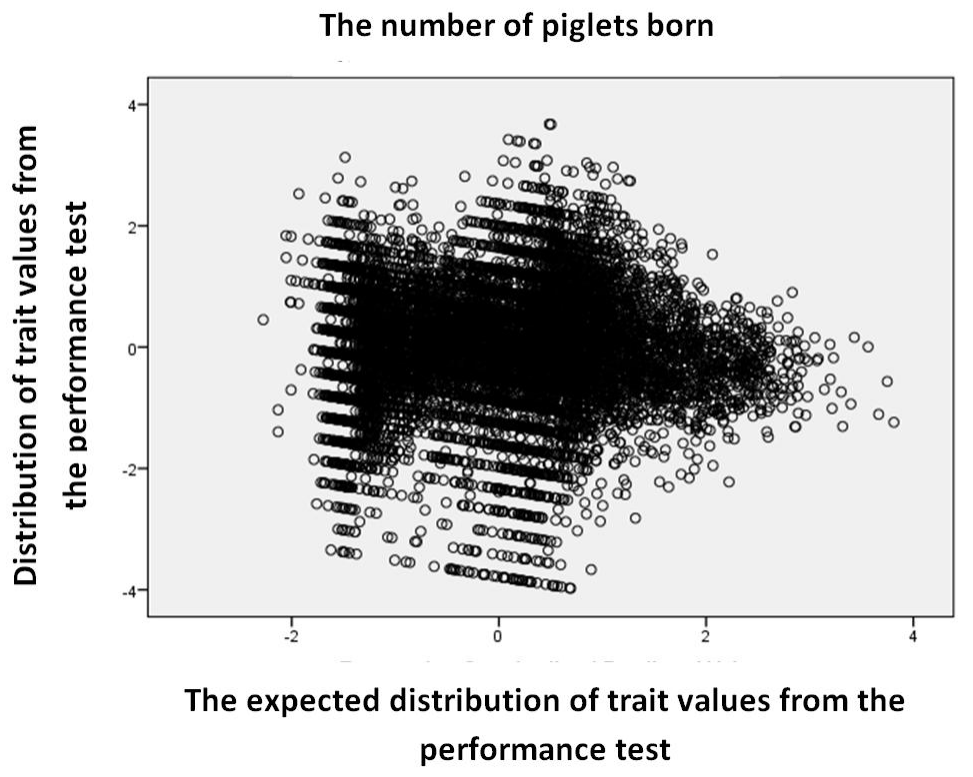

Figure 3. Graphic display of concentration quintiles of total standard residue.

The multiple regression represents a model that includes all the variables with which the analysis was started, regardless of the degree of their importance and the presence of large multicollinearity. When the multi-collinearity is large, many variables have similar meanings and their comprehensive integration is unnecessary. "Stepwise" regression solves this problem and eliminates the variables that overlap with others 
and therefore contribute little, or not at all, to the accuracy in forecasting models.

When selecting and installing "Stepwise" regression model we use the following statistical and analytical values: coefficient of determination, residual mean square, corrected coefficient of determination, $\mathrm{Cp}$ Mallows indicator, PRESS, AIC (Akaike's Information Criterion), SBC (Schwartz's Bayesian Criterion), BIC (Bayes' Information Criterion) PC
(Amemiya's Prediction Criterion). We monitor the impact of variables involved as statistically significant in relation to the dependent variable "average live".

In Table 2, we set the model in which the value of the included variables is number of beds, MLD depth and fat thickness in the dorsal part represent the key explanation while the other variables are excluded from the model.

Table 2. Setting up the model for "Stepwise" regression of the dependent variable "average live" with the total sample of all breeding races

\begin{tabular}{|c|c|c|}
\hline Model & Variables involved & Method \\
\hline 1 & Number of litters & $\begin{array}{l}\text { Probability of included variable }<=0.50 \\
\text { Probability of excluded variable }>=100\end{array}$ \\
\hline 2 & MLD depth & $\begin{array}{l}\text { Probability of included variable }<=0.50 \\
\text { Probability of excluded variable }>=100\end{array}$ \\
\hline 3 & Back-fat thickness & $\begin{array}{l}\text { Probability of included variable }<=0.50 \\
\text { Probability of excluded variable }>=100\end{array}$ \\
\hline
\end{tabular}

a) Dependent variable: Average live

The following analysis shows the strength of the correlation of each independent variable in explaining of the variation of the dependent variable "average live". Multiple correlation coefficients $\mathrm{R}$ are tracked in order to determine the bond strength of each dependent variable.
Analyzing the obtained correlation coefficient in Table 3, we concluded that a single linear relation between the dependent variable "average live" and independent variables: the number of litters, the MLD depth and back-fat thickness, is individually positive and weak.

Table 3. Correlation coefficients and their standard error

\begin{tabular}{llccc} 
Model & $\mathrm{R}$ & $\mathrm{R}^{2}$ & $\begin{array}{c}\text { Adapted coefficient } \\
\text { of determination }\end{array}$ & Standard error \\
\hline 1. & $0.163^{\mathrm{a}}$ & 0.026 & 0.025 & 2.79786 \\
2. & $0.238^{\mathrm{b}}$ & 0.056 & 0.053 & 2.75706 \\
3. & $0.313^{\mathrm{c}}$ & 0.098 & 0.093 & 2.69779 \\
\hline
\end{tabular}

Dependent variable: Average live

a) Prerequisite: (con.), the number of litters

b) Prerequisite: (con.), the number of litters, MLD depth

c) Prerequisite: (con.), the number of litters, MLD depth, the back-fat thickness

In column $\mathrm{D}$, a multiple correlation coefficient of independent variable "number of litters" and the dependent variable "average live" in this case occurs in the amount of 0.163 , which represents the weaker bond strength. By including the other variables, first MLD-depth, and then the back-fat thickness, these coefficients grow to a value of 0.313 .
In column $\mathrm{R} 2$, by including all selected independent variables, which showed adequate statistical significance in the previous step analysis, in correlation with the dependent variable, the coefficient of determination grows to a value of 0.098 , which represents a $9.80 \%$ impact on the dependent variable that can be explained by the independent variable, which leads to the conclusion that the bond strength between the variables "average live" and all 
independent variables: number of litters, the MLD depth and back-fat thickness, very poor, which is not uncommon in multiple regression.

Based on the analysis of statistical significance of independent variables in relation to the dependent variable "average live" with the total sample of all races (Table 4), it was concluded that all independent variables have a real connection with the dependent variable "average live". In the next step, we observed Table 5, where the regression coefficient $B$ and the standardized regression coefficient $\beta$ are statistically significant.

Table 6 shows the independent variables that were not statistically significant, and which were excluded from the model.

Table 4. F test - Analysis of statistical significance of independent variables in relation to the dependent variable "average live" with the total sample of all races

\begin{tabular}{|c|c|c|c|c|c|c|}
\hline & Model & $\begin{array}{c}\text { Sum of all mean } \\
\text { squares }\end{array}$ & Df & Mean squares & $\mathrm{F}$ & Sig. \\
\hline \multirow{3}{*}{1} & \multirow{3}{*}{$\begin{array}{l}\text { Total residue of } \\
\text { regression }\end{array}$} & 114.631 & 1 & \multirow{3}{*}{$\begin{array}{c}114.631 \\
7.828\end{array}$} & \multirow{3}{*}{14.644} & \multirow{3}{*}{$0.000^{\mathrm{b}}$} \\
\hline & & 4211.475 & 538 & & & \\
\hline & & 4326.106 & 539 & & & \\
\hline \multirow{3}{*}{2} & \multirow{3}{*}{$\begin{array}{l}\text { Total residue of } \\
\text { regression }\end{array}$} & 244.167 & 2 & \multirow{3}{*}{$\begin{array}{c}122.083 \\
7.601\end{array}$} & \multirow{3}{*}{16.061} & \multirow{3}{*}{$0.000^{\mathrm{c}}$} \\
\hline & & 4081.939 & 537 & & & \\
\hline & & 4326.106 & 539 & & & \\
\hline \multirow{3}{*}{3} & \multirow{3}{*}{$\begin{array}{l}\text { Total residue of } \\
\text { regression }\end{array}$} & 425.055 & 3 & \multirow{3}{*}{$\begin{array}{c}141.685 \\
7.278\end{array}$} & \multirow{3}{*}{19.467} & \multirow{3}{*}{$0.000^{\mathrm{d}}$} \\
\hline & & 3901.051 & 536 & & & \\
\hline & & 4326.106 & 539 & & & \\
\hline
\end{tabular}

a) Dependent variable: Average live

b) Prerequisite: (con.), the number of litters

c) Prerequisite: (con.), the number of litters, MLD depth

d) Prerequisite: (con.), the number of litters, MLD depth back-fat thickness

Table 5. Regression coefficients which are included in the test model and their statistical significance for the dependent variable "average live" for the total sample of all races

\begin{tabular}{|c|c|c|c|c|c|c|}
\hline & & Non-standard & fficients & $\begin{array}{c}\text { Standard } \\
\text { coefficients }\end{array}$ & & \\
\hline & Model & $\begin{array}{l}\text { Coefficient of } \\
\text { regression } \\
\text { (B) }\end{array}$ & $\begin{array}{c}\text { Standard } \\
\text { error }\end{array}$ & $\begin{array}{l}\text { Coefficient of } \\
\text { regression } \\
(\beta)\end{array}$ & $\mathrm{t}$ & Sig. \\
\hline & con. & 9.569 & 0.190 & & 50.335 & 0.000 \\
\hline 1 & Number of litters & 0.201 & 0.052 & 0.163 & 3.827 & 0.000 \\
\hline & con. & 7.391 & 0.560 & & 13.197 & 0.000 \\
\hline 2 & Number of litters, & 0.229 & 0.052 & 0.186 & 4.392 & 0.000 \\
\hline & MLD depth & 0.033 & 0.008 & & 4.128 & 0.000 \\
\hline & con. & 7.758 & 0.553 & & 14.030 & 0.000 \\
\hline & Number of litters, & 0.270 & 0.052 & 0.219 & 5.225 & 0.000 \\
\hline 3 & MLD depth, back-fat & 0.048 & 0.008 & 0.254 & 5.728 & 0.000 \\
\hline & thickness & -0.082 & 0.016 & -0.220 & -4.985 & 0.000 \\
\hline
\end{tabular}

a) Dependent variable: Average live 
Table 6. Regression coefficients that we exclude from the test model for the dependent variable "average live" for the total sample of all races

\begin{tabular}{lccccc}
\multicolumn{1}{c}{ Model } & $\begin{array}{c}\text { Coefficient of } \\
\text { regression } \\
\text { (B) }\end{array}$ & t & Significance & $\begin{array}{c}\text { Partial } \\
\text { correlation }\end{array}$ & Deviation \\
\hline Ex. & $0.030^{\mathrm{b}}$ & 0.703 & 0.482 & 0.030 & 0.995 \\
Mass at the end of test, & $-0.025^{\mathrm{b}}$ & -0.577 & 0.564 & -0.025 & 0.984 \\
Age at the end of test, & $-0.116^{\mathrm{b}}$ & -2.683 & 0.008 & -0.115 & 0.949 \\
Mass gain during the test, & $0.035^{\mathrm{b}}$ & 0.806 & 0.421 & 0.035 & 0.940 \\
Loin-fat thickness, Back- & $-0.044^{\mathrm{b}}$ & -1.033 & 0.302 & -0.045 & 1.000 \\
fat thickness, MLD depth, & $-0.129^{\mathrm{b}}$ & -3.047 & 0.002 & -0.130 & 0.989 \\
SI, percentage of meat in & $0.175^{\mathrm{b}}$ & 4.128 & 0.000 & 0.175 & 0.983 \\
the body & $-0.041^{\mathrm{b}}$ & -0.972 & 0.332 & -0.042 & 0.996 \\
Ex. & $0.059^{\mathrm{b}}$ & 1.384 & 0.167 & 0.060 & 0.997 \\
Mass at the end of the & $0.060^{\mathrm{c}}$ & 1.419 & 0.157 & 0.061 & 0.968 \\
test, Age at the end of the & $-0.087^{\mathrm{c}}$ & -1.954 & 0.051 & -0.084 & 0.891 \\
test, Mass gain during the & $-0.098^{\mathrm{c}}$ & -2.266 & 0.024 & -0.097 & 0.937 \\
test, Loin-fat thickness, & $-0.034^{\mathrm{c}}$ & -0.727 & 0.467 & -0.031 & 0.817 \\
Back-fat thickness, SI, & $-0.153^{\mathrm{c}}$ & -3.280 & 0.001 & -0.140 & 0.798 \\
Percentage of meat in the & $-0.220^{\mathrm{c}}$ & -4.985 & 0.000 & -0.211 & 0.862 \\
body & $-0.101^{\mathrm{c}}$ & -2.315 & 0.021 & -0.100 & 0.910 \\
Ex. & $0.050^{\mathrm{c}}$ & 1.194 & 0.233 & 0.052 & 0.994 \\
Mass at the end of test, & $0.033^{\mathrm{d}}$ & 0.777 & 0.437 & 0.034 & 0.950 \\
Age at the end of test, & $-0.064^{\mathrm{d}}$ & -1.465 & 0.143 & -0.063 & 0.881 \\
Mass gain during the test, & $-0.039^{\mathrm{d}}$ & -0.879 & 0.380 & -0.038 & 0.856 \\
Loin-fat thickness, Back- & $-0.045^{\mathrm{d}}$ & -0.999 & 0.318 & -0.043 & 0.815 \\
fat thickness, MLD depth, & $-0.085^{\mathrm{d}}$ & -1.743 & 0.082 & -0.075 & 0.707 \\
SI, percentage of meat in & $-0.072^{\mathrm{d}}$ & -1.666 & 0.096 & -0.072 & 0.891 \\
the body & $0.028^{\mathrm{d}}$ & 0.676 & 0.499 & 0.029 & 0.982 \\
\hline a) & & & & & \\
\hline
\end{tabular}

a) Dependent variable: Average live

At the end, we obtain the following final regression model with B coefficients:

$\mathrm{Y}=7.758+0.270$ (number of litters) +0.048 (MLD depth) -0.082 (loin-fat thickness).

\section{DISCUSSION}

In the results of this study, gilts mass at the end of the test in relation to the number of live-born piglets in the total sample of all races, a sample of pure breeds and programmed crossbreeds, shows no significance, and has no influence or its influence is very small. In this study, the average weight of gilts at the end of the test, observed in the entire herd was $106.69 \mathrm{~kg}$. In their study Roongsitthicha et al. (2013) also show the results related to the weight of gilts at the end of the test; where the average weight of gilts was $139.10 \mathrm{~kg}$ which is significantly higher than in the results of our research. Roongsitthicha et al. (2013), in particular, point out that in relation to the number of live-born piglets any increase in body weight of gilts for $10 \mathrm{~kg}$ cause an increase of 0.06 in litter.

If we consider the age of gilts at the end of the test in relation to the number of live-born piglets in the total sample of all races, there is no significance, and it has no influence or the influence is very small. In accordance with these results there is a possibility that the influence of age in certain herds was masked by other influences. So Lucia et al. (2000) emphasize the importance of factors affecting reproductive period of sows, which are associated with the preparation and entry of gilts in reproduction phase. Referring to earlier studies, we need to mention a number of key factors like: age at first estrus, age at first insemination and successful conception and age at first farrowing (Schukken 
et al., 1994; Le Cozler et al., 1998; Tummaruk et al., 2001; 2007, and Knauer et al., 2011).

The average age of gilts entering puberty is 195 days in the research (Tummaruk et al., 2007) and 200 ( \pm 28) days (Tummaruk et al., 2009b), but considerable variation was observed by (Le Cozler et al, 1999; and is Tummaruk et al., 2007), wherein said impacts by Tummaruk et al. (2009a) described previously. Given that the work Tummaruk et al., 2004; 2007; 2009a were realized in the tropics, the number of days is from 7 to 14 days less than on farms in Europe. In studies conducted by Knauer et al. (2011) in the US, where the sows in group had contact with the boar than 5 minutes per day, it was found that $70 \%$ of gilts in the group together entered puberty (average 2 months after forming a group).

The results of this study were analyzed by observing the entire herd, the average age at the end of the test was 200.27 days, which coincides with the age at the beginning of puberty in research of Tummaruk et al., (2009b). The results are consistent with the results of Radović et al. (2012), who analyzed gilts in the tests and noted that the average age at the end of the test was 203.56 days, while Gogić et al. (2012) found a lower average age at the end of test - 183.46 days.

Average daily gain achieved in the test was analyzed by observing the entire herd and it was $533.33 \mathrm{~g}$. Average gain of $601.00 \mathrm{~g}$ was shown in the study of Roongsitthicha et al. (2013), while they pointed out the observation that in gilts groups based on the intensive gain, larger litters were recorded in the groups with the gain of 601 to $650 \mathrm{~g}$, than in the groups with $552 \mathrm{~g}$ to $600 \mathrm{~g}$ of gain. It should be noted that Szulc et al. (2013) in their study noted that the gain below $600.00 \mathrm{~g}$ may result in smaller litters, whereby the aforementioned authors refer to the survey conducted by the Bocian et al. (2010).

The daily gain in test based on relation to the number of live-born piglets in the total sample of all races, pure breeds and crossbreeds in this research, showed no significance, so we came to the conclusion that there is no influence or the influence is very small.
Sows with recorded faster growth have a higher concentration and faster circulation of somatomedin C (insulin-like growth factor-1) and insulin (Cox, 1997), which has an impact on increasing the volume of ovulation and reduce the possibility of follicular atresia (Britt et al., 1988). research Lundeheim et al. (2010) point out that rapid growth (period up to $100.00 \mathrm{~kg}$ ) of the piglets in the test (future gilts) was negatively correlated with the size of the litter, but also positively correlated with the intensity of growing piglets during lactation.

Research of Lundeheim et al. (2010) point out that rapid growth (period up to $100.00 \mathrm{~kg}$ ) of the piglets in the test (future gilts) was negatively correlated with the size of the litter, but also positively correlated with the intensity of growing piglets during lactation.

According to the results of Amaral Filha et al. (2010), the higher thickness of the back-fat (from 18 to $23 \mathrm{~mm}$ ) in sows does not increase the total number of piglets, compared with those with lower back-fat thickness (from 10 to $15 \mathrm{~mm}$ ), suggesting that the back-fat thickness has the smaller influence on the size of the litter compared to the total weightgain. In this study, the obtained results indicate that the back-fat thickness in the lumbar region in relation to the number of live-born piglets on the total sample of all races, pure races and crossbreed races does not show significance, i.e. it has no influence or it is very small.

The average values of the back-fat thickness in the back and loin parts were, observing all races, at average value of $8.85 \mathrm{~mm}$ and $9.53 \mathrm{~mm}$, which corresponds to the results of $9.7 \mathrm{~mm}$, found by Popavac et al. (2014).

Tummaruk et al. (2009b) points out that in gilts of the landrace race, excellent reproductive life and large litters were recorded at animals where the thickness of the back-fat was between $17.00 \mathrm{~mm}$ and $25.00 \mathrm{~mm}$. Also, the gilts of the Yorkshire breed, selected by the thinner back-fat, had about two live-born piglets per litter more than in gilts that were not selected by this feature in the performance test (Nelson et al., 1990).

The depth of MLD in relation to the number of live-born piglets shows significance. Observing the entire population, the average depth of MLD 
was $40.35 \mathrm{~mm}$. In literature reviews, the authors agreed that the correlations and size of the litter between the first and the second breeding are usually less, comparing to the correlation between the size of the litter of the second and subsequent breeding. This was pointed out by Krupa and Wolf (2013), referring to previous research by Hermesch et al., 2000; Hanenberg et al., 2001; Wolf et al., 2002 and Serenius et al., 2001). Krupa and Wolf (2013), referring again to earlier research (Hermesch et al., 2000; Hanenberg et al., 2001; Wolf et al., 2002 and Serenius et al., 2001) recommends that during the research we especially treat the first and again all the other breeding, in terms of variables, which is not the case in this study because of the circumstances that did not allow it.

The number of litters in relation to the number of live-born piglets shows significance on the sample of all races. The average number of litters in the total sample of this study was 3.09. In literature reviews, the authors agreed that the correlations and size of the litter between the first and second breeding are usually less compared to correlation between the size of the litter of the second and subsequent breeding. This was pointed out by Krupa and Wolf (2013), referring to previous research of Hermesch et al., 2000; Hanenberg et al., 2001; Wolf et al., 2002 and Serenius et al., 2001). Krupa and Wolf (2013), referring again to earlier researches (Hermesch et al., 2000; Hanenberg et al., 2001; Wolf et al., 2002 and Serenius et al., 2001) recommends that during the research the first litter treats specially, and the rest litters also, in terms of variables, which is not the case in this study because of the circumstances that did not allow it.

\section{CONCLUSION}

The significance of the early forecasting of the reproductive potential of sows, based on the results achieved in the test performance, represents an important moment in deciding on the inclusion of sows in the breeding process. In the results of this study, (the influence of the performance test characteristics on the later reproductive performance of sows, based on the analysis of the statistical significance of independent variables in relation to the dependent variable "average live"), it was concluded that all independent variables have some solid connection with the dependent variable "average live". By analyzing the obtained coefficients of correlation, it was concluded that the individual linear relationship between the dependent variable "average live" and independent variables: "the number of litters", "the MLD depth" and "the back-fat thickness", is individually positive and weak. The value of the multiple correlation coefficient of an independent variable "the number of litters" and the dependent variable "average live" in our study is 0.163 , which represents a link of weaker strength. By including the following variables, firstly "the MLD depth" and then "the back-fat thickness", these coefficients slightly increase to a value of 0.313. By including all selected independent variables, that showed the adequate statistical significance, in correlation with the dependent variable, the determination coefficient rises to a value of 0.098 which represents $9.80 \%$ of the influence on the dependent variable, which can be explained by the independent variables, and that leads to the conclusion that the strength of the relationship between the variables "average live" and all the independent variables: "the number of litters", "the MLD depth" and "the back-fat thickness" is very weak, which is not a rare case in multiple regression.

\section{ACKNOWLEDGEMENTS}

The work is a part of the research on the project TP-20087, financed by the Ministry of Sciences and Technological Development, Republic of Serbia, from 2010. to 2017.

\section{REFERENCES}

AMARAL FILHA, W.; BERNARDI, M.L.; WENTZ, I.; BORTOLOZZO, F.P. Reproductive performance of gilts according to growth rate and backfat thickness at mating. Anim. Reprod. Sci., v.121, p.139-144 201, 2010.

BOCIAN, M.; JANKOWIAK, H.; GRAJEWSKA, S. et al. Ocena wartości hodowlanej i rozpłodowej loch rasy wielkiej białej polskiej i polskiej białej zwisłouchej $\mathrm{z}$ regionu kujawsko-pomorskiego. Rocz. Nauk. Zootech., v.37, p.137-144, 2010. 
BRITT, J.H.; ARMSTRONG, D.J.; COX, N.M. Metabolic interfaces between nutrition and reproduction in pigs. In: INTERNATIONAL CONGRESS ON ANIMAL REPRODUCTION AND ARTIFICIAL INSEMINATION, 11., 1988, Belfield. Proceedings... Dublin, Ireland, [s.n.], 1988. p.117-125.

COX, N. Control of follicular development and ovulation rate in pigs. J. Reprod. Fertil., Suppl., v.52, p.31-46, 1997.

ELIASSON-SELLING, L. Puberty and oestrus syptome in gilts. 2001. Disertacion

(Doctor).

GERASIMOV, V.; PRON, E.; DANILOVA, T. The effect of genotype and final live weight after finishing on economic traits of pigs. Pig News Inform., v.18, p.35, 1997.

GOGIĆ M.; PETROVIĆ M.; ŽIVKOVIĆ B. et al. The effect of various factors on traits of performance tested gilts. Biotechnol. Anim. Husbandry, v.28, p.313-322, 2012.

HANENBERG, E.H.A.T.; KNOL, E.F.; MERKS J.W.M. Estimates of genetic parameters for reproduction traits at different parities in Dutch Landrace pigs. Livest. Prod. Sci., v.69, p.179186, 2001

HERMESCH S.; LUXFORD B.G.; GRASER H.U. Genetic parameters for lean meat yield, meat quality, reproduction and feed efficiency traits for Australian pigs. 3. Genetic parameters for reproduction traits and genetic correlations with production, carcase and meat quality traits. Livest. Prod. Sci., v.65, p.261-270, 2000.

KNAUER M.T., CASSADY J.P., NEWCOM, D.W., SEE, M.T. Phenotypic and genetic correlations between gilt estrus, puberty, growth, composition, and structural conformation traits with first-litter reproductive measures. Journal of animal science, v. 89(4), p.935-942, 2011.

KRUPA, E.; WOLF, J. Simultaneous estimation of genetic parameters for production and litter size traits in Czech Large White and Czech Landrace pigs. Czech J. Anim. Sci., v.58, p.429436, 2013.

LE COZLER, Y.; DAGORN, J.; LINDBERG, J.E.; AUMAITRE, A.; DOURMAD, J.Y. Effect of age at first farrowing and herd management on long-term productivity of sows. Livest. Prod. Sci., v.53, p.135-142, 1998.
LUCIA JR., T.; DIAL G.D.; MARSH W.E. Lifetime reproductive performance in female pigs having distinct reasons for removal. Livest. Prod. Sci., v.63, p.213-222, 2000.

LUNDEHEIM N.; CHALKIAS H.; RYDHMER, L. Teat number, fattening performance and litter traits in pigs, estimates of genetic correlations. Proceedings of the World Congress on Genetics Applied to Livestock Production, Volume Species breeding: Pig breeding - Poster Sessions 0181, 2010.

NELSON A.H., MABRY J.W., BENYSHEK L.L., MARKS M.A. Correlated response in reproduction, growth and composition to selection in gilts for extremes in age at puberty and backfat, Livestock Production Science, 24(3): 237-247, 1990.

POPOVAC, M.; PETROVIĆ, M.; RADOJKOVIĆ, D. et al. The assessment of genetic potential in performance tested gilts by means of selection indexes method. Genetika, v.46, p.95-104, 2014.

RADOVIĆ I.; PETROVIĆ M.; TEODOROVIĆ M.; MESAROŠ P. Kada izlučiti krmaču. Agroznanje, v.4, p.1, 2003.

RADOVIĆ, 亡̌.; PETROVIĆ, M.; PARUNOVIĆ, N. The effect of genotype and year on traits of performance tested gilts. Biotechnol. Anim. Husbandry, v.28, p.463-468, 2012.

ROONGSITTHICHAI, A.; CHEUCHUCHART, P.; CHATWIJITKUL, S.; CHANTAROTHAI, O.; TUMMARUK, P. Influence of age at first estrus, body weight, and average daily gain of replacement gilts on their subsequent reproductive performance as sows. Livest. Sci., v.151, p.238-245, 2013.

ROSERO, D.S.; VAN HEUGTEN, E.; ODLE, J. Sow and litter response to supplemental dietary fat in lactation diets during high ambient temperatures. J. Anim. Sci., v.90, p.550-559, 2012.

SCHUKKEN, Y.H.; BUURMAN, J.; HUIRNE, R.B. Evaluation of optimal age at first conception in gilts from data collected in commercial swine herds. J. Anim. Sci., v.72, p.1387-1392, 1994. 
SERENIUS, T.; SEVÓN-AIMONEN, M.L.; MÄNTYSAARI, E.A. The genetics of leg weakness in Finnish Large White and Landrace populations. Livest. Prod. Sci., v.69, p.101-111, 2001.

STANČIĆ, I. et al. Prolonged preinsemination anestrus in gilts. Contemporary agriculture, v.57, p.97-105, 2009a.

STANCIC, L.B.; RADOVIĆ, V.I.; BOŽIĆ, A.; GAGRČIN, M.; ANDERSON R. Sow fertility after conventional ai with insemination doses of various volumes and spermatozoa number*. Contemp. Agric., v.58, p.62-66, 2009 b.

STANCIC, L.B.I.; ŠAHINOVIĆ, H.R. Biotechnology in the reproduction of pigs. 1998. Monographs (Monographs) - Faculty of Agriculture, Institute for Animal Husbandry, University of Novi Sad, SRB.

SZULC, K.; KNECHT, D.; JANKOWSKAMAKOSA, A.; SKRZYPCZAK, E.; NOWACZEWSKI, S. The influence of fattening and slaughter traits on reproduction in Polish Large White sows. Ital. J. Anim. Sci., v.12, p.e3, 2013.

TEODOROVIĆ M.; RADOVIĆ I. Svinjarstvo, udžbenik. Novi Sad: Poljoprivredni fakultet, 2004.

TUMMARUK, P.; LUNDEHEIM, N.; EINARSSON, S.; DALIN, A.M. Influence of birth litter size, birth parity number, growth rate, backfat thick $\neg$ ness and age at first mating of gilts on their reproductive performance as sows. Anim. Reprod. Sci., v.66, p.225-237, 2001.

TUMMARUK P.; KESDANGSAKONWUT S.; KUNAVONGKRIT A. Relationships among specific reasons for culling, reproductive data and gross-morphology of the genital tracts in gilts culled due to reproductive failure in Thailand. Theriogenology, v.71, p.369-375, 2009a.
TUMMARUK， P.; TANTASUPARUK，W.; TECHAKUMPHU, M.; KUNAVONGKRIT, A. The association between growth rate, body weight, backfat thickness and age at first observed oestrus in crossbred Landracex Yorkshire gilts. Anim. Reprod. Sci., v.110, p.108122, 2009b.

TUMMARUK, P.; TANTASUPARUK, W.; TECHAKUMPHU, M.; KUNAVONGKRIT, A. Effect of season and outdoor climate on litter size at birth in purebred Landrace and Yorkshire sows in Thailand. J. Vet. Med. Sci., v.66, p.477482, 2004.

TUMMARUK, P.; TANTASUPARUK, W.; TECHAKUMPHU, M.; KUNAVONGKRIT, A. Age, body weight and backfat thickness at first observed oestrus in crossbred LandracexYorkshire gilts, seasonal variations and their influence on subsequence reproductive performance. Anim. Reprod. Sci., v.99, p.167181, 2007.

WISE, T.; YOUNG, L.D.; POND, WG. Reproductive, endocrine and organ weight differences of swine selected for high or low serum cholesterol. J. Anim. Sci., v.71, p.27322738, 1993.

WOLF J.; PEŠKOVIČOVÁ D.; GROENEVELD E.; WOLFOVÁ M. Genetische Parameter für Fruchtbarkeitsmerkmale beim Schwein - eine detaillierte Analyse der ersten vier Würfe unter Verwendung verschiedener Modelle mit zufälligem Merkmalen und den Würfen. Züchtungskunde, v.74, p.46-55, 2002. 